\title{
Floristic diversity of the soil weed seed bank in a rice-growing area of Brazil: in situ and ex situ evaluation
}

\author{
Mário Luiz Ribeiro Mesquita ${ }^{1,4}$, Leonaldo Alves de Andrade ${ }^{2}$ and Walter Esfrain Pereira ${ }^{3}$
}

Received: 5 November, 2012. Accepted: 8 June, 2013

\begin{abstract}
The objective of this study was to compare the ex situ and in situ floristic diversity of the soil weed seed bank of a rice field in northeastern Brazil. In a rice field in the county of Bacabal, located in the state of Maranhão, thirty $25-\mathrm{m}^{2}$ plots were laid out. From 15 plots, soil samples $(6 /$ plot; $n=90)$ were taken with a soil probe $(25 \times 16 \times 3 \mathrm{~cm})$ and placed in aluminum trays in the greenhouse. From the remaining 15 plots, weed samples $(6 /$ plot; $n=90)$ were taken with the same soil probe. The number of seeds was estimated by germination. We evaluated the numbers of species and individuals, as well as the density, frequency, abundance and importance value (IV) for each species. Diversity was computed by the Shannon index $\left(H^{\prime}\right)$. We recorded 13,892 individuals (among 20 families, 40 genera and 60 species), of which 11,530 (among 50 species) germinated ex situ and 2,362 (among 34 species) germinated in situ. The family Cyperaceae had the highest number of species (16), followed by Poaceae (10). The dominant species, in situ and ex situ, were Schoenoplectus juncoides (IV=47.4\%) and Ludwigia octovalvis (IV=34.8\%), respectively. Floristic diversity was higher ex situ $\left(H^{\prime}=2.66\right)$. The information obtained here could help determine the infestation potential of these species, which could lead to improved management strategies.
\end{abstract}

Key words: Cyperaceae, competition, biological invasion, phytosociology, smallholder farmers

\section{Introduction}

Weeds have adverse impacts on crop yield and can interfere with crop growth and development through mechanisms of allelopathy and competition (for water, nutrients, light and space). In aerobic rice fields, uncontrolled weed growth can reduce yields by up to $96 \%$ (Chauhan \& Johnson 2011).

The production of a huge number of small seeds is an important survival strategy developed by weeds to counter control methods in agroecosystems. After dispersal, the seeds remain on the soil surface or are buried through the actions of various biotic and abiotic agents, thus forming a seed bank which becomes the main source of weeds in the ecosystem.

Several factors affect weed seed germination, chief among which are variations in soil temperature and moisture; light intensity; and the physiological aspects of seeds, particularly seed dormancy. When favorable conditions occur, seeds germinate; seedlings are recruited and produce new propagules, enriching the soil seed bank and future weed populations.

Despite its ecological and economic importance, little is known about the soil weed seed bank in the tropics, particu- larly in fields tended by subsistence farmers in northeastern Brazil. In addition, there are very few data available on invasive herbaceous vegetation. Therefore, there is a need to carry out floristic surveys of weeds in order to determine their patterns of occurrence in crop fields. Studies on weed seed bank ecology in this region are crucial to improving control strategies.

Various studies recently conducted in the tropics have been aimed at identifying weed species in crop fields, in pastures and in the corresponding seed banks (Silva \& Dias-Filho 2001; Lacerda et al. 2005; Begum et al. 2006; Lopes et al. 2006; Ikeda et al. 2008; Isaac \& Guimarães 2008; Andrade et al. 2009; Costa et al. 2009; Kamoshita et al. 2010). However those studies were focused on agribusiness rather than on generating scientific knowledge for use in subsistence farming.

In situ and ex situ studies are needed in order to understand weed seed bank germination dynamics and its relationship with invasive flora in crop fields. This might contribute to predicting infestations and could lead to improved management strategies to minimize the negative impact that invasive plants have on crop development and yield. The objective of the present study was to assess the

${ }^{1}$ Universidade Estadual do Maranhão, Centro de Estudos Superiores de Bacabal, Depto. Ciências Agrárias, Bacabal, MA, Brazil 
floristic diversity and phytosociological structure, in situ and $e x$ situ, of the soil weed seed bank in a rice field in northeastern Brazil.

\section{Material and methods}

\section{Study site}

This study was carried out in a 3-ha rice field, selected from among those within a representative smallholder farming community located in the county of Bacabal ( $\left.4^{\circ} 13^{\prime} 30^{\prime \prime} \mathrm{S} ; 44^{\circ} 46^{\prime} 48^{\prime \prime} \mathrm{W}\right)$, which is in the Mearim region (central portion) of the state of Maranhão, in northeastern Brazil. According to the Köppen climate classification system, the climate of the region is type Aw, tropical hot and humid with a rainy season (January through June) and a dry season (July through December). The average temperature is $25^{\circ} \mathrm{C}$, and the average annual rainfall is approximately $1800 \mathrm{~mm}$.

The most important economic activities in the region are extensive livestock production and subsistence farming, the latter practiced in a slash and burn fashion. The prevalent soils in the region are plinthosols, argisols and, to a lesser degree, latosols (EMBRAPA 2008).

Thirty $25-\mathrm{m}^{2}$ plots were laid out, in pairs. In half of those plots, we collected soil samples ( 6 per plot, $\mathrm{n}=90$ ) using a soil probe $(25 \times 16 \times 3 \mathrm{~cm})$, maintaining a minimum distance of $1 \mathrm{~m}$ from the plot border. The probe was introduced into the soil to a depth of $3 \mathrm{~cm}$, and all material enclosed by the internal perimeter was withdrawn for the subsequent ex situ evaluation of the weed seed bank. This procedure was carried out in November 2008, the end of the dry season and one month before rice planting. Samples were placed in black plastic bags, identified and transported to the greenhouse at the Fazenda Escola (Farm School) of the Maranhão State University Center for Agricultural Sciences, in the city of São Luís. In January 2009, the soil samples were placed in aluminum trays $(25 \times 16 \times 5 \mathrm{~cm})$, in accordance with the methodology proposed by Forcella et al. (2003). The trays were pierced to facilitate drainage, and the samples were irrigated daily to promote seed germination. Three aluminum trays containing washed sand were added as controls. This was done due to the possibility of contamination by local weed species via seed rain. However, during the experiment, no such contamination was observed. In addition, portions of the soil samples were collected at a depth of $0-20 \mathrm{~cm}$ and packaged in plastic bags to be sent for physical and chemical analysis according to the methodology described by EMBRAPA (1997).

The chemical and physical attributes of the soil at the study site were as follows: organic matter $=26 \mathrm{~g} \mathrm{dm}^{-3} ; \mathrm{pH}$ in $0.01 \mathrm{M} \mathrm{CaCl}_{2}=5.8 ; \mathrm{P}=5.0 \mathrm{mg} \mathrm{dm}{ }^{-3} ; \mathrm{K}^{+}=5.6 ; \mathrm{Ca}^{2+}=40$; $\mathrm{Mg}^{2+}=27 ; \mathrm{H}+\mathrm{Al}^{3+}=20 ; \mathrm{Na}^{+}=9.5 \mathrm{mmol}_{\mathrm{c}} \mathrm{dm}^{-3} ; \mathrm{Al}^{3+}=$ $0 \mathrm{mmol}_{c} \mathrm{dm}^{-3} ; \mathrm{C}=1.48 \%$; sand $=53 \%$; silt $=30 \%$; clay $=17 \%$; silt $/$ clay ratio $=1.76$; and sandy loam texture.

\section{Data collection}

Once every 15 days over a period of 130 days, weed seedlings were identified and removed from the trays. At 60 days after the start the experiment, irrigation was suspended for two weeks and the soil was turned in order to promote the germination of the seeds located near the bottom of the trays. Seven assessments were made: four before water restriction and three after.

For the subsequent in situ evaluation of the weed seed bank, we collected weed samples from the remaining 15 plots ( 6 per plot, $\mathrm{n}=90$ ). We collected those samples during the rainy season (January and February 2009), using the same soil probe employed in the collection of the soil samples. Weed samples were withdrawn one day before the first and second weedings; i.e., there were three samplings in January and three in February.

Botanical material from each species was collected in triplicate and prepared exsiccates. The species were preserved by common techniques and were incorporated into the collection of the Rosa Mochel Herbarium at the Center for Biological Studies of Maranhão State University. Botanical identification was achieved by analysis of the external morphology of the plants (vegetative and reproductive parts), by referring to the specialized literature, by comparison with other species and by consulting an expert. Specimens that could not be identified down to the species level at the time of sampling were transplanted to plastic pots and cultivated until reaching the flowering stage. The floristic list was organized according to the classification system established in the Angiosperm Phylogeny Group II guidelines (APG II 2003).

Phytosociological structure was assessed by common parameters such as absolute and relative values of frequency, density, abundance and importance value for each species (Muller-Dombois \& Ellenberg 1974). Species were organized in a Microsoft Excel 2007 spreadsheet. Computation was performed with the following equations:

\section{Absolute frequency $=$ number of sampling units with} species present/total number of sampling units

Relative frequency $=$ species absolute frequency/ sum of all absolute frequencies $\times 100$

Absolute density = total number of individuals of a species/total sampled area

Relative density = absolute density of a species/ sum of all absolute densities $\times 100$

Absolute abundance $=$ total number of individuals of a species/total number of sampling units containing that species

Relative abundance $=$ absolute abundance of a species/sum of all absolute abundances $\times 100$

Importance value $=$ relative frequency + relative density + relative abundance 
Floristic diversity was assessed by the Shannon index $\left(H^{\prime}\right)$ based on natural logarithm which considers equal weight among rare and abundant species. Higher values of $H^{\prime}$ indicate greater floristic diversity (Shannon \& Weaver 1949). The Shannon index was computed by the following formula:

$$
H^{\prime}=-\sum_{I=1}^{S} p i \ln p i
$$

where $\ln$ is the natural logarithm, and $p i=n i / N$, ni being the number of sampled individuals of species $i$ and $N$ being the total number of sampled individuals.

\section{Results}

In the soil weed seed bank, we recorded a total of 13,892 individuals, belonging to 20 families, 40 genera and 60 species. Of those, 11,530 individuals within 50 species were recorded ex situ and 2,362 individuals within 34 species were recorded in situ (Tab. 1). The overall density was 3,859 plants $\mathrm{m}^{-2}$.
The families with the highest species richness were Cyperaceae $(n=16)$, Poaceae $(n=10)$ and Fabaceae $(n=6)$. Those families collectively accounted for $53.3 \%$ of the species identified. In contrast, ten families (Amaranthaceae, Euphorbiaceae, Lamiaceae, Loganiaceae, Marantaceae, Nyctaginaceae, Plantaginaceae, Portulacaceae, Solanaceae, Thelypteridaceae and Turneraceae), half of the families recorded, were represented by only one species each.

The genera with the highest species richness were Cyperus $(\mathrm{n}=9)$; Phyllanthus $(\mathrm{n}=4)$; Fimbristylis $(\mathrm{n}=3)$; Digitaria $(\mathrm{n}=3)$; and Crotalaria $(\mathrm{n}=3)$. These genera accounted for $36.3 \%$ of weed community floristic composition in soil weed seed bank. Ten species were found only in situ Alternanthera tenela; Ageratum conyzoides; Cyperus meyenianus; Cyperus rotundus; Desmodium incanum; Sida santaremensis; Thalia geniculata; Digitaria horizontalis; Guadua angustifolia; and Thelypteris dentata.) and 24 species were found only ex situ (Erechtites hieraciifolius; Cyperus aggregatus; Cyperus diffusus; Cyperus haspan; Cyperus sphacelatus; Rhynchospora nervosa; Calopogonium mucunoides; Crotalaria incana; Crotalaria retusa; Crotalaria spectabilis; Desmodium adscedens; Hyptis suaveolens; Spigelia anthelmia; Sida rhombifolia;

Table 1. Number of individuals recorded, in situ and ex situ, in the soil weed seed bank of a rice field in northeastern Brazil.

\begin{tabular}{|c|c|c|c|}
\hline Species & Family & In situ & Ex situ \\
\hline Alternathera tenella Colla & Amaranthaceae & 89 & - \\
\hline Ageratum conyzoides $\mathrm{L}$. & Asteraceae & 2 & - \\
\hline Eclipta alba (L.) Hassk & Asteraceae & 4 & 1 \\
\hline Emilia coccinea (Sims) G. Don & Asteraceae & 11 & 18 \\
\hline Erechtites hieracifolius (L). Raf. ex DC. & Asteraceae & - & 2 \\
\hline Commelina diffusa Burm. f. & Commelinaceae & 31 & 95 \\
\hline Murdannia nudiflora (L.) Brennan & Commelinaceae & 27 & 121 \\
\hline Cyperus aggregatus (Willd.) Endl. & Cyperaceae & - & 19 \\
\hline Cyperus compressus L. & Cyperaceae & 38 & 5 \\
\hline Cyperus diffusus $\mathrm{L}$. & Cyperaceae & - & 49 \\
\hline Cyperus haspan $\mathrm{L}$. & Cyperaceae & - & 72 \\
\hline Cyperus iria $\mathrm{L}$. & Cyperaceae & 102 & 775 \\
\hline Cyperus luzulae (L.) Rottb. ex Retz. & Cyperaceae & 60 & 63 \\
\hline Cyperus meyenianus Kunth & Cyperaceae & 2 & - \\
\hline Cyperus rotundus $\mathrm{L}$. & Cyperaceae & 12 & - \\
\hline Cyperus sphacelatus Roth & Cyperaceae & - & 1228 \\
\hline Fimbristylis autumnalis (L.) Roem. \& Schult. & Cyperaceae & 122 & 25 \\
\hline Fimbristylis dichotoma (L.) Vahl & Cyperaceae & 351 & 341 \\
\hline Fimbristylis miliaceae (L.) Vahl & Cyperaceae & 139 & 270 \\
\hline Kyllinga brevifolia Rottb. & Cyperaceae & 66 & 11 \\
\hline Rhynchospora nervosa (Vahl) Boeck & Cyperaceae & - & 279 \\
\hline Schoenoplectus juncoides (Roxb.) Palla & Cyperaceae & 596 & 1825 \\
\hline Scleria lithosperma (L.) Sw. & Cyperaceae & 79 & 371 \\
\hline
\end{tabular}


Table 1. Continuation.

\begin{tabular}{|c|c|c|c|}
\hline Species & Family & In situ & Ex situ \\
\hline Chamaesyce hirta (L.) Millsp. & Euphorbiaceae & 71 & 56 \\
\hline Calopogonium mucunoides Desv. & Fabaceae & - & 10 \\
\hline Crotalaria incana $\mathrm{L}$. & Fabaceae & - & 1 \\
\hline Crotalaria retusa $\mathrm{L}$. & Fabaceae & - & 1 \\
\hline Crotalaria spectabilis Roth & Fabaceae & - & 6 \\
\hline Desmodium adscendens (Sw.) DC. & Fabaceae & - & 15 \\
\hline Desmodium incanum DC. & Fabaceae & 1 & - \\
\hline Hyptis suaveolens (L.) Poit. & Lamiaceae & - & 17 \\
\hline Spigelia anthelmia $\mathrm{L}$. & Loganiaceae & - & 9 \\
\hline Sida rhombifolia $\mathrm{L}$. & Malvaceae & - & 421 \\
\hline Sida santaremensis $\mathrm{H}$. Monteiro & Malvaceae & 19 & - \\
\hline Urena lobata $\mathrm{L}$. & Malvaceae & - & 9 \\
\hline Thalia geniculata $\mathrm{L}$. & Marantaceae & 2 & - \\
\hline Boerhavia erecta $\mathrm{L}$. & Nyctaginaceae & - & 452 \\
\hline Ludwigia leptocarpa (Nutt.) H. Hara & Onagraceae & - & 103 \\
\hline Ludwigia octovalvis (Jacq.) P. H. Raven & Onagraceae & 338 & 2159 \\
\hline Phyllanthus corcovadensis Muell & Phyllanthaceae & - & 23 \\
\hline Phyllanthus niruri L. & Phyllanthaceae & 2 & 75 \\
\hline Phyllanthus tenellus Roxb. & Phyllanthaceae & - & 12 \\
\hline Phyllanthus urinaria $\mathrm{L}$. & Phyllanthaceae & - & 1 \\
\hline Lindernia crustacea (L.) F. Muell & Plantaginaceae & 94 & 1823 \\
\hline Cenchrus echinatus $\mathrm{L}$. & Poaceae & - & 2 \\
\hline Cynodon dacytlon (L.) Pers. & Poaceae & - & 6 \\
\hline Digitaria ciliaris (Retz.) Koeler & Poaceae & 2 & 47 \\
\hline Digitaria horizontalis Willd. & Poaceae & 31 & - \\
\hline Digitaria sanguinalis (L.) Scop. & Poaceae & - & 2 \\
\hline Eleusine indica (L.) Gaertn. & Poaceae & 6 & 9 \\
\hline Eragrostis ciliaris (Retz.) Koeler & Poaceae & 2 & 46 \\
\hline Guadua angustifolia Kunth & Poaceae & 6 & - \\
\hline Panicum maximum Jacq. & Poaceae & 1 & 281 \\
\hline Panicum trichoides Sw. & Poaceae & 21 & 16 \\
\hline Talinum paniculatum (Jacq.) Willd. & Portulacaceae & - & 4 \\
\hline Oldenlandia corymbosa $\mathrm{L}$. & Rubiaceae & 17 & 309 \\
\hline Spermacoce verticilata $\mathrm{L}$. & Rubiaceae & - & 3 \\
\hline Physalis angulata $\mathrm{L}$. & Solanaceae & - & 1 \\
\hline Thelypteris dentata (Forssk.) E. P. St. John & Thelypteridaceae & 6 & - \\
\hline Turnera subulata $\mathrm{Sm}$. & Turneraceae & 2 & 52 \\
\hline
\end{tabular}

Urena lobata; Boerhavia erecta; Ludwigia leptocarpa; Phyllanthus corcovadensis; Phyllanthus tenellus; Phyllanthus urinaria; Cenchrus echinatus; Cynodon dactylon; Digitaria sanguinalis; Talinum. paniculatum; Spermacoce verticilata; and Physalis angulata). However, another 24 species were found both in situ and ex situ: Eclipa alba; Emilia coccinea; Commelina difusa; Murdannia nudiflora; Cyperus compressus;
Cyperus iria; Cyperus luzulae; Fimbristylis autumnalis; Fimbristylis dichotoma; Fimbristylis miliacea; Kyllinga brevifolia; Schoenoplectus juncoides; Scleria lithosperma; Chamaesyce hirta; Ludwigia octovalvis; Phyllanthus niruri; Lindernia crustacea; Digitaria ciliaris; Eleusine indica; Eragrostis ciliaris; Panicum maximum; Panicum trichoides; Oldenlandia corymbosa; and Turnera subulata. 
The highest floristic richness, with the highest number of families, genera and species, was observed ex situ (Fig. 1). The ex situ density was 3,206 plants $\mathrm{m}^{-2}$, five times higher than the 653 plants $\mathrm{m}^{-2}$ observed in situ.

In the greenhouse, approximately $80 \%$ of seeds germinated by day 60 of the study. Germination peaked at the first assessment, on day 25, which coincided with the start of the rainy season in the region, when weed germination and emergence from the soil weed seed bank increase. Germination stabilized by the fifth assessment, on day 115 (Fig. 2).

The dominant species in situ and ex situ (by importance value) were Schoenoplectus juncoides (47.4\%) and Ludwigia octovalvis (34.8\%), respectively (Tab. 2). Floristic diversity was greater ex situ $\left(H^{\prime}=2.66\right)$ than in situ $\left(H^{\prime}=2.53\right)$. The high number of individuals and species found ex situ contributed to the great floristic diversity in this area.

\section{Discussion}

Species of the family Cyperaceae largely dominated the soil weed seed bank evaluated. Formation of a seed bank represents an important regeneration component for many species of this family (Leck \& Schütz 2005). This result is in agreement with those of similar studies carried out in other tropical regions, such as that conducted by Kamoshita et al. (2010), who observed that $86 \%$ of species present in the seed banks of 22 rice fields in Cambodia belonged to

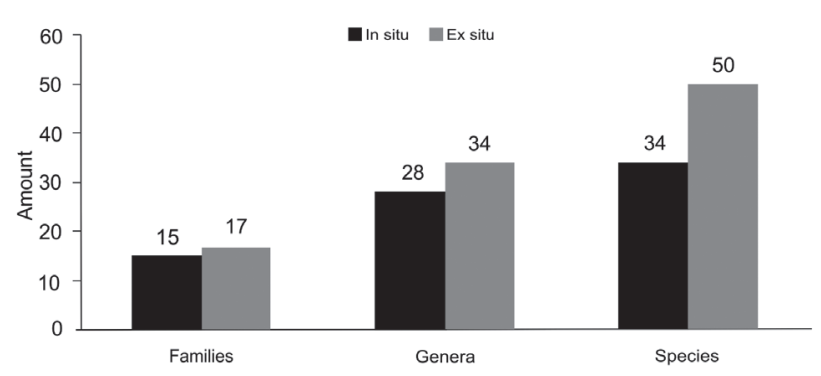

Figure 1. Number of families, genera and species in the soil weed seed bank of a rice field in the county of Bacabal, in the state of Maranhão, northeastern Brazil.

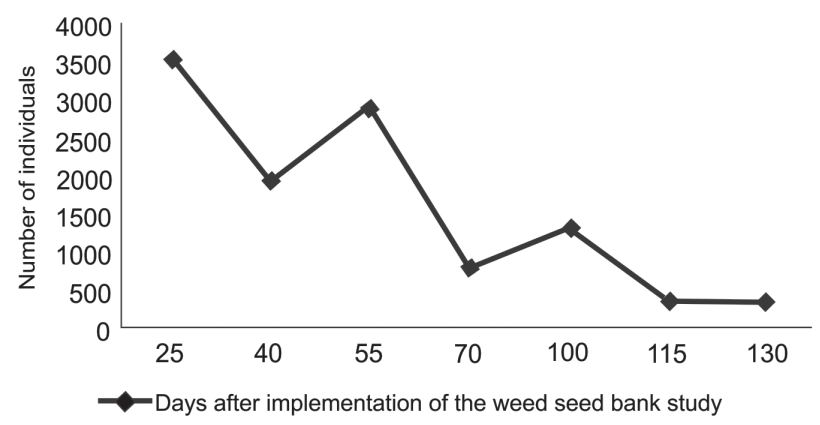

Figure 2. Germination curve of the soil weed seed bank ex situ from a rice field in the county of Bacabal, in the state of Maranhão, northeastern Brazil. the Cyperaceae family. In a study conducted in Nepal, Bhatt \& Singh (2007) reported that $37 \%$ of the species present in the weed seed bank belonged to that same family.

As previously mentioned, ten (50\%) of the families identified in our study were represented by only one species (Tab. 1). It is a generally accepted concept in floristic surveys that a great number of such families indicates a pattern characteristic of sites with high diversity (Ratter et al. 2003). Species that were present in situ and ex situ demonstrated great plasticity (the capacity to adapt to different sites), as well as tolerance to human activities and stress conditions imposed by environmental factors.

Differences observed between the amount of seeds germinated in situ (in the field) and ex situ (in the greenhouse) might be explained by various factors including seed and seedling losses in the field due to the activities of microorganisms, insects, rodents, lizards, birds and other animals. According Ghersa \& Martinez-Ghersa (2000), weed seed losses due to predators range from $5 \%$ to $15 \%$. However, in a post-dispersal weed seed study carried out in rice fields in the Philippines, Chauhan et al. (2010) observed that Solenopsis geminata (fire ants), which were the main predators of weed seeds, were responsible for the removal of $98 \%$, $88 \%$ and $75 \%$ of D. ciliaris, E. indica and E. colona seeds, respectively, from the soil surface over a period of only 14 days. Another possible explanation for the differences observed in the present study is that occasional periods of soil water stress and losses (due to intraspecific and interspecific competition) resulted in germination failure, as observed by Herault \& Hiernaux (2004) in a weed seed and population dynamics study carried out in Africa. Similar observations were reported by Isaac \& Guimarães (2008), in a study of the weed seed bank and emergent flora in crop fields in the state of Mato Grosso, in western Brazil. In the greenhouse, our seeds were protected from predators and systematically irrigated, which did not happen in the field. Maia et al. (2004), studying weed seed banks in natural fields, also observed that soil moisture content was one the most important abiotic factors affecting the patterns of vegetation. Other authors have also cited soil water content as a determinant of weed seed bank germination (Munhoz \& Felfili 2006; Vivian et al. 2008). In our ex situ study, the seeds were further protected by the removal of weed seedlings from the trays after the assessments, which eliminated competition, and by the fact that we controlled abiotic factors such as air relative humidity, light and temperature.

The higher germination rates observed in the soil weed seed bank in the first 60 days of our study is probably due to dormancy breaking because of greater exposure to sunlight and temperature variation, as observed by Baskin \& Baskin (1998) and Benech-Arnold et al. (2000). Similar results were reported by Zimdahl et al. (1988) in a study conducted in the Philippines, in which $50 \%$ of the seeds in a soil weed seed bank in a rice field germinated in the first six weeks. In addition, Begum et al. (2006) observed a germination peak 
Table 2. Phytosociological parameters of the dominant species, in situ and ex situ, in the soil weed seed bank of a rice field in northeastern Brazil.

\begin{tabular}{lccccccccc}
\hline & \multicolumn{3}{c}{ In situ } & \multicolumn{5}{c}{ Ex situ } \\
\hline Species & RF & RD & RA & IV\% & Species & RF & RD & RA & IV\% \\
S. juncoides & 8.8 & 25.3 & 13.3 & 47.4 & L. octovalvis & 7.0 & 18.7 & 9.1 & 34.8 \\
F. dichotoma & 12.3 & 14.9 & 5.6 & 32.8 & S. juncoides & 7.0 & 15.8 & 7.7 & 30.5 \\
L. octovalvis & 5.3 & 14.4 & 12.6 & 32.3 & L. crustacea & 7.0 & 15.8 & 7.7 & 30.5 \\
F. miliacea & 2.6 & 5.9 & 10.4 & 18.9 & C. sphacelatus & 7.0 & 10.6 & 5.2 & 22.8 \\
F. autumnalis & 6.5 & 5.2 & 3.7 & 15.4 & C. iria & 6.2 & 6.7 & 3.7 & 16.6 \\
L. crustacea & 6.7 & 4.0 & 2.7 & 13.4 & F. dichotoma & 1.2 & 3.0 & 8.6 & 12.8 \\
C. iria & 4.1 & 4.3 & 4.9 & 13.3 & B. erecta & 6.6 & 3.9 & 2.0 & 12.5 \\
A. tenella & 3.2 & 3.8 & 5.4 & 12.4 & R. nervosa & 0.9 & 2.4 & 8.8 & 12.1 \\
C. hirta & 6.7 & 3.0 & 2.1 & 11.8 & S. lithosperma & 7.0 & 3.2 & 1.6 & 11.8 \\
S. lithosperma & 4.4 & 3.4 & 3.5 & 11.3 & S. rhombifolia & 3.4 & 3.7 & 3.6 & 10.7 \\
\hline
\end{tabular}

$\mathrm{RF}$ - relative frequency; RD - relative density; RA - relative abundance; IV - importance value.

at 30 days in a soil weed seed bank in a rice field in Malaysia. These results suggest that weed seed bank reserve at our study site might be drastically decreased because management practices hinder or prevent germination, as well as potentially preventing new seed deposition into this bank via mechanisms such as seed rains. In crop fields where the soil is not turned for planting, as was the case at our study site, and where the input of new weed seeds is minimized, the rate of decline of the weed seed bank can vary according to the weather and climate (Garcia 1995).

According to Roberts \& Feast (1973), in temperate climate regions the weed seed bank declines $32 \%$ a year. In contrast, in tropical regions the weed seed bank is generally smaller and the decline tends to be more rapid because, according to Garcia (1995), there is a high seedling recruitment rate due to favorable climate conditions for seed germination, which persist for longer periods than in temperate regions; high seed mortality due to attack by pathogens and predators, as well as high relative humidity and higher temperatures, which favor biotic agents; seedling mortality due to seed germination in short, hot dry periods that can occur during the rainy season; a shorter duration or even the absence of seed dormancy of many weed species; and low seed viability.

The density of viable seeds found in the soil weed seed bank in the present study $\left(3,859\right.$ seeds $\left.\mathrm{m}^{-2}\right)$ is lower than the values reported by Carmona (1995) for the savanna of central Brazil-22,313 seeds $\mathrm{m}^{-2}$ in lowland areas and 6,768 seeds $\mathrm{m}^{-2}$ in areas of crop rotation (soybean, fallow, bean) - as well as the 6,188 seeds $\mathrm{m}^{-2}$ reported by Lacerda et al. (2005) in conventional tillage in the state of São Paulo, in southeastern Brazil, the 48,821 seeds $\mathrm{m}^{-2}$ found in a study conducted in Africa (Buah et al. 1996) and the 5,313 seeds $\mathrm{m}^{-2}$ reported for cassava fields in the state of Amazonas, in northern Brazil (Costa et al. 2009). However, it is higher than the 451 seeds $\mathrm{m}^{-2}$ found by Gasparino et al. (2006), in crop fields in the state of Paraná, in southern Brazil, and the 2,028 seeds $\mathrm{m}^{-2}$ found by Isaac \& Guimarães (2008) in direct seeding in the state of Mato Grosso, in western Brazil.

The dominance of species in the soil weed seed bank might be related not only to cultural practices and crop history but also to the reproductive capacity of the weed species. All species cited here are propagated exclusively by seeds, except for F. dichotoma and S. lithosperma (Cyperaceae), which also propagate asexually, by rhizomes (Lorenzi 2008).

According to the International Rice Research Institute (2010), one plant of L. octovalvis (Onagraceae) is capable of producing 250,000 seeds. Among the species within the family Cyperaceae, $S$. juncoides can produce 82,098 seeds $\mathrm{m}^{-2}$ (Leck \& Schütz 2005). The species F. miliaceae, F. dichotoma and C. iria can produce 10,000, 6,500 and 5,000 seeds per plant, respectively (Lorenzi 2008; IRRI 2010).

\section{Conclusions}

The floristic diversity of the soil weed seed bank was higher ex situ than in situ. The density of the soil weed seed bank was five times ex situ than in situ. The dominant species in the soil weed seed bank evaluated, in situ and ex situ, were Schoenoplectus juncoides and Ludwigia octovalvis, respectively. Our findings could help predict infestation and could lead to improved weed management strategies in rice-growing areas, especially for smallholder farmers in the state of Maranhão.

\section{References}

Andrade, M.V.M.; Andrade, A.P.; Silva, D.S.; Bruno, R.L.A.; Guedes, D.S.A 2009. Levantamento florístico e estrutura fitossociológica do estrato herbáceo e subarbustivo em áreas de caatinga no Cariri paraibano. Revista Caatinga 22: 229-237.

Angiosperm Phylogeny Group. 2003. An update of the Angiosperm Phylogeny Group classification for the orders and families of flowering plants. APG II, Botanical Journal of the Linnean Society 141: 399-436. 
Baskin, C.C.; Baskin, J.M. 1998. Seeds, ecology, biogeography and evolution of dormancy and germination. New York, Academic Press.

Begum, M.; Juraimi, A.S.; Rastan, S.O.B.S.; Amartalingam, R.; Man, A.A.B. 2006. Seedbank and seedling emergence characteristics of weeds in ricefield soils of the muda granary area in north-west peninsular Malaysia. Biotropia 13: 11-21.

Benech-Arnold, R.L.; Sanchez, R.A.; Forcela, F.; Kruk, B.C.; Ghersa, C.M. 2000. Environmental control of dormancy in weed seed banks in soil. Field Crops Research 60: 105-122.

Bhatt, M.D.; Singh, S.P. 2007. Soil seed banks dynamics of weed flora in upland and lowland rice paddy cultivation areas of far western Nepal. Scientific World 5: 54-59.

Buah, J.N.; Carson, A.G.; Haizel K.A. 1996. The problem of weeds under continuous cropping systems in the scrub and thicket vegetation belt of the Central Region, Ghana. Ghana Journal of Agricultural Science 29: 81-90.

Carmona, R. 1995. Banco de sementes e estabelecimento de plantas invasoras em agroecossistemas. Planta Daninha 13: 3-9.

Chauhan, B.S.; Migo, T.; Westerman, P.R.; Johnson, D.E. 2010. Post dispersal of weed seeds in rice fields. Weed Research 50: 553-560.

Chauhan, B.S.; Johnson, D.E. 2011. Row spacing and weed control timing affect yield of aerobic rice. Field Crops Research 121: 226-231.

Costa, J.R.; Mitja, D.; Fontes, J.R.A. 2009. Bancos de sementes de plantas invasoras em cultivos de mandioca na Amazônia central. Planta Daninha 27: 665-671.

Empresa Brasileira de Pesquisa Agropecuária. 1997. Manual de métodos de análise de solos. 2 ed. Rio de Janeiro, EMBRAPA.

Empresa Brasileira de Pesquisa Agropecuária. 2008. Sistema brasileiro de classificação de solos. 2 ed. Rio de Janeiro, EMBRAPA.

Forcella, F.T.; Webster, T.; Cardina J. 2003. Protocols for weed seed banks determination in agro-ecosystems. In: I. R. Labrada (Ed.). Weed management for developing countries, Adeendum. FAO - Rome. Plant Production and Protection Paper 120: 3-18.

Garcia, M.A. 1995. Relationship between weed community and soil seed bank in a tropical agro- ecosystem. Agriculture, Ecosystem and Environment 55: 139-147.

Gasparino, D.; Malavasi, U.C.; Malavasi, M.M.; Souza, I. 2006. Quantificação do banco de sementes sob diferentes usos do solo em área de domínio ciliar. Revista Árvore 30: 1-9.

Ghersa, C.M.; Martinez-.Ghersa, M.A. 2000. Ecological correlates of weed seed size and persistence in the soil under different tilling systems: implications for weed management. Field Crops Research 67: 141-148.

Herault, B.; Hiernaux, P. 2004. Soil seed bank vegetation dynamics in Sahelian fallows; the impact of past cropping and current grazing treatments. Journal of Tropical Ecology 20: 683-691.

Ikeda, F.S.; Mitja, D.; Vilela, L.; Silva, J.C.S. 2008. Banco de sementes em cerrado sensu stricto sob queimada e sistemas de cultivo. Pesquisa Agropecuária Brasileira 43: 667-673.
International Rice Research Institute (IRRI). 2010. Rice knowledge bank. http://www.knowledgebank.irri.org/ipm/index.php/weeds-crophealth-2743 (Acesso em 25/01/2010).

Isaac, R.A.; Guimarães, S.C. 2008. Banco de sementes e flora emergente de plantas daninhas. Planta Daninha 26: 521-530.

Kamoshita, A.; Ikeda, H.; Yamagishi, J.; Ouk, M. 2010. Ecophysiological study on weed seed bank and weeds in Cambodian paddy fields with contrasting water availability. Weed Biology and Management 10: $261-272$.

Lacerda, A.L.S.; Victoria Filho, R.; Mendonça, C.G. 2005. Levantamento do banco de sementes em dois sistemas de manejo do solo irrigados por pivô central. Planta Daninha 23: 1-7.

Leck, M.A.; Schütz, W. 2005. Regeneration of Cyperaceae, with particular reference to seed ecology and seed banks. Perspectives in Plant Ecology, Evolution and Systematics 7: 95-133.

Lopes, K.P.; Souza, V.C.; Andrade, L.A.; Dornelas, G.V.; Bruno, R.L.A. 2006. Estudo de bancos de sementes em povoamentos florestais puros e em uma capoeira de floresta ombrófila aberta, no município de Areia, PB, Brasil. Acta Botanica Brasilica 20: 105-113.

Lorenzi, H. 2008. Plantas invasoras do Brasil: terrestres aquáticas, parasitas e tóxicas. 4. ed. Nova Odessa, Instituto Plantarum.

Maia, F.C.; Medeiros, R.B.; Pillar, V.P. Focht, T. 2004. Soil seed bank variation patterns according to environmental factors in a natural grassland. Revista Brasileira de Sementes 26: 126-137.

Muller-Dombois, D.; Ellenberg, H. 1974. Aims and methods of vegetation ecology. New York, John Wiley \& Sons.

Munhoz, C.B.R.; Felfili, J.M. 2006. Fitossociologia do estrato herbáceosubarbustivo de uma área de campo sujo no Distrito Federal, Brasil. Acta Botanica Brasilica 20: 671-685.

Ratter, J.A.; Bridgewater, S.; Ribeiro, J.F. 2003. Analysis of the floristic composition of the Brazilian cerrado vegetation III: Comparison of the woody vegetation of 376 areas. Edinburgh Journal of Botany 60: 57-109.

Roberts, H.A.; Feast, P.M. 1973. Changes in the number of viable seeds in the soil under different regimes. Weed Research 13: 298-303.

Shannon, C.E.; Weaver, W. 1949. The Mathematical Theory of Communication. Urbana, University of Illinois Press.

Silva, D.S.M.; Dias Filho, M.B. 2001. Banco de sementes de plantas invasoras em solo cultivado com pastagens de Brachiaria brizantha e Brachiaria humidicola de diferentes idades. Planta Daninha 19: 179-185.

Vivian, R.; Gomes Jr., F.G.; Chamma, H.M.C.P.; Silva, A.A.; Fagan, E.B.; Ruiz, S.T. 2008. Efeito da luz e da temperatura na germinação de Alternathera tenella, Conyza bonariensis e Digitaria ciliaris. Planta Daninha 26: 507-513.

Zimdahl, R.L.; Moody, K.; Lubigan, R.; Castin, E. 1988. Patterns of weed emergence in tropical soil. Weed Science 36: 603-608. 